\title{
At Swim, Two Boys: \\ In Search of the Nation of Freedom
}

\author{
by Aída Díaz-Bild \\ University of La Laguna, Spain
}

Copyright (c) 2007 by Aída Díaz-Bild. This text may be archived and redistributed both in electronic form and in hard copy, provided that the author and journal are properly cited and no fee is charged for access.

\begin{abstract}
The aim of this paper is to show how in At Swim, Two Boys, Jamie O'Neill demystifies one of the crucial moments in the history of Ireland by means of the subversive and liberating power of laughter. He points out the contradictions and absurdities of the Rising and unmasks the fanaticism and dogmatism of the revolutionaries. In order to undermine the heroic vision of the insurrection and the months that preceded it, O'Neill has created a series of characters, Anthony MacMurrough, his aunt Eveline and Mr Mack, through whom he offers us a different perspective of the political milieu of the time and testifies to the many-sidedness of human beings and the chaotic, random and absurd essence of life.
\end{abstract}

Key Words. Humour, subversion, absurdity, fanaticism, demystify, Irish revolution, patriotism, religion.

Resumen. El objetivo de este artículo es demostrar cómo en At Swim, Two Boys, Jamie O’Neill desmitifica uno de los momentos cruciales en la historia de Irlanda a través del poder subversivo y liberador de la risa. O’Neill explora las contradicciones y ambigüedades del levantamiento de 1916 y desenmascara el fanatismo y el dogmatismo de los revolucionarios. El autor subvierte toda lectura heroica de la insurrección y de los meses que la precedieron a través de una serie de personajes, Anthony MacMurrough, su tía Eveline y Mr Mack, cuyas reacciones ante los acontecimientos históricos en los que se ven involucrados no sólo permiten ofrecer una visión distinta del ambiente político de la época, sino también poner de manifiesto la pluralidad del ser humano y el carácter esencialmente caótico, absurdo y aleatorio de la vida.

Palabras clave. Humor, subversión, absurdo, fanatismo, desmitificación, revolución irlandesa, patriotismo, religión.

Humour has been in the last decades a subject of great interest for scholars from a variety of different disciplines and areas -history, philosophy, literary theory, sociology, anthropology, psychology- who have tried to rescue it from the sombre and marginal place to which it had been confined and defend the vital role it plays in human existence. The task has not been an easy one, since it has involved the destruction of a pervasive and wellestablished myth, that of tragedy being profound, wise and sublime and comedy a trivial and inferior genre incapable of dealing with the great problems that preoccupy humanity. James Thurber has described this situation with great irony: "the tragic is the robust wine, the dramatic the champagne of the arts, while comedy is the ginger ale" (Cit. in Hyers 1996: 56). Scholars have tried to eliminate this existing prejudice against humour and vindicate its positive, creative, liberating and subversive character. They have emphasised the subversive function that laughter performs and have argued that 
humour does not offer us a trivial vision of reality, but a profound and serious response to the contradictions of life. This essay will focus precisely on how these two aspects of comedy are fully exploited in At Swim, Two Boys, by Jamie O’Neill.

Any approach to laughter must necessarily begin with Mikhail Bakhtin, one of the critics who has best understood the carnivalesque and creative power of laughter. ${ }^{1}$ According to the Russian critic, for the comic feature nothing is eternal or stable, everything can and must be renewed. Laughter destroys fear and reverence before an object, before a world, bringing us close to them, and allowing us to analyse, question and revaluate them. The notion of an absolute and indisputable truth is rejected and the relativity of prevailing doctrines, beliefs or ideas is welcomed. Reality is perceived as heteroglot and contradictory and not as a unified whole. Whereas official, serious culture represents the triumph of a truth already established, laughter leads to a temporary liberation from the sanctioned order and prevailing ideas. Fear, violence, prohibition and limitation, the features of seriousness are defeated by laughter: "Complete liberty is possible only in the completely fearless world" (Bakhtin 1984: 47). Laughter offers us the possibility of having a new outlook on the world and allows the old order to be replaced by a new one. Humour is vital in life since it functions as a corrective and complement to seriousness:

True ambivalent and universal laughter does not deny seriousness but purifies and completes it. Laughter purifies from dogmatism, from the intolerant and the petrified; it liberates from fanaticism, and pedantry, from fear and intimidation, from didacticism, naïveté and illusion, from the single meaning, the single level, from sentimentality. Laughter does not permit seriousness to atrophy and to be torn away from the one being, forever incomplete. It restores this ambivalent wholeness (Bakhtin 1984: 122-3).

\footnotetext{
${ }^{1} \mathrm{I}$ am concerned in this article with laughter as a universal, liberating, subversive, creative force that can be found in all kinds of human manifestations and not with the specific nature of comic Irish literature, although there are some key texts on the matter, such as Vivian Mercier's The Irish Comic Tradition or Don L.F. Nilsen's Humor in Irish Literature
}

Bakhtin's ideas on laughter are shared by many other authors, among them Conrad Hyers who in The Spirituality of Comedy approaches comedy from a mythological and religious point of view. His starting point is that reality is essentially contradictory and confusing and that the function of the comic mode is precisely to reflect this incongruity. For the comic spirit nothing is merely black or white, superior or inferior, bad or good, but ambiguous and therefore relative. The comic hero reminds us that in spite of our dreams of grandeur and our triumphs, we are mortal, fallible and foolish: "For the comic protagonist, life is never so simple, so sensible, so logical, or so organized as our inspirational visions, our theatrical plots, our historical reconstructions, or our great works of art might wish to suggest” (61). The comic vision appreciates the ambiguities of truth and goodness and therefore confounds all rigid and fixed categories: "Flexibility is, after all, the characteristic of life; rigidity is the sign of death" (55). Hyers, like Bakhtin, believes that the tragic mode must be tempered and qualified by the comic mode if absolutism, dogmatism and intolerance are to be avoided: "Unqualified seriousness is dehumanizing and dangerous. It is the crucifier of freedom and the human spirit" (69). Humour warns us against idolatry and tyranny that lead to fear and lowly obedience.

In the same line as Bakhtin and Hyers, though from a philosophical perspective, John Morreall also affirms that humour celebrates the incongruities of life, right down to the basic one "between the eager fret of our life and its final nothingness" (Morreall 1983: 128). Humour provides us with the necessary distance and perspective to perceive the ambiguities and absurdities of human existence and, therefore, functions as a powerful liberating and subversive force.

Humour is "incompatible with both hero worship and fear" (102) and this derives from its connection with creativity, imagination and flexibility of perspective. The spirit of humour knows that things can be looked at in more than one way and thus never gets trapped in the net of absolute truths.

Wylie Sypher also defends the subversive power of laughter and goes so far as to say that the comic artist can be more intransigent than the tragic one, since, instead of accepting 
reality as it is, as the latter does, it adopts an attitude of resistance, rebellion and irreverence towards the society to which he belongs. But Sypher's emphasis is more on comedy's acceptance of the incongruities of life. Sypher explains that the devastating reality of the twentieth century with its world wars, concentration camps and big lies have forced human beings to become aware of the absurdity of life and to face the chaos and nonsense of the world. Moreover, admitting the irrational and contradictory in our lives implies recognizing that the comic is part of our existence: "For all our science, we have been living through an age of Un-reason, and have learned to submit to the Improbable, if not to the Absurd. And comedy is, in Gautier's words, a logic of the absurd" (Sypher 1980: 197). In an age of disorder, irrationalism and fragmentary lives comedy can represent the human plight better than tragedy: "For tragedy needs the 'noble', and nowadays we seldom can assign any usable meaning to 'nobility'. The comic now is more relevant, or at least more accessible, than the tragic" (201).

Marcel Gutwirth follows the path of the critics already mentioned in Laughing Matter. On the one hand, he emphasises how laughter's euphoric recognition of man's limitations and humour's acceptance of our contradictions make us wiser. As a matter of fact, to be capable of laughing at our own follies and absurdities requires a certain amount of courage:

to laugh in the face of folly (our own) and lostness (our own), however wisfully, is to reach for the prize of wisdom, inglorious perhaps, unlikely to win us the crown of a saint or mantle of a guru but secure in the unfazed recognition of the little we are - so much wind, as Montaigne reminds us, but for all that content to make a noise in the world, glad simply to be (Gutwirth 1993: 187).

On the other hand, Gutwirth defends the subversive power of comedy. Laughter gives us the necessary freedom to undermine everything we value, fear or which oppresses us, whether it be dignity, social decorum or our adherence to a series of principles. By doing so, humour celebrates the victory of the inferior over the superior, of the bad over the good. For a brief period of time, since the "Lord of Misrule, however, is king only for a day" (73) we rest from the daily struggle and occupations: "For a blessed moment we enter a godlike impunity, our foes disarmed, our fears stilled, our aggressions rendered permissible by a mutual compact of blamelessness" (130)

Northrop Frye in his well-known Anatomy of Criticism also defends the subversive aspect of comedy. The fact that the comic dramatist is on the side of the young hero who defeats the paternal figure and thus creates a new society, clearly shows the revolutionary essence of the comic genre. At the same time, Frye underlines comedy's rejection of any kind of dogmatism or single vision of life:

Thus the movement from pistis to gnosis, from a society controlled by habit, ritual bondage, arbitrary law and the older characters to a society controlled by youth and pragmatic freedom is fundamentally, as the Greek words suggest, a movement from illusion to reality. Illusion is whatever is fixed or definable, and reality is best understood as its negation: whatever reality is, it's not that (Frye 1990: 169-70).

Other scholars have concentrated more on just one of the two aspects of laughter I am dealing with in this article. Thus, Dana F. Sutton has pointed out that comedy is essentially subversive because of its demystifying function and its criticism of society. Sutton, like some of the critics mentioned above, believes that this revolutionary character clearly derives from the Graeco-Roman comedy. He summarizes the festive and antiauthoritarian elements that comedy has inherited from the classical genre as follows: "disrespectful antinomianism, antiauthorityarianism, individualism, and hedonism, coupled with a strong element of social disruption or even inversion" (Sutton 1994: 107). Sutton rejects those theories that tend to suggest that comedy, despite its iconoclastic content, is essentially an instrument of social control, a means "of reconciling the spectator to the very things it purports to attack" (114).

He admits that society sanctions disruptive holidays and comedy as a means of venting the pressure created by social discipline and thus preserve the social order, but adds that the disruption that may be caused by holidays and comedies is potentially far from negligible. It is nonetheless less damaging than any kind of explosions that would be likely to occur if the community's collective surplus store of psychic energy were to be kept bottled up altogether (117). 
He admits that society sanctions disruptive holidays and comedy as a means of venting the pressure created by social discipline and thus preserve the social order, but adds that the disruption that may be caused by holidays and comedies is potentially far from negligible. It is nonetheless less damaging than any kind of explosions that would be likely to occur if the community's collective surplus store of psychic energy were to be kept bottled up altogether (117).

I cannot finish this exploration of those scholars who have emphasised the subversive aspect of humour without briefly referring to the figure of Sigmund Freud and his famous Jokes and their Relation to the Unconscious. Freud must be present in any work on humour because he has been a source of inspiration for those who came after him, either to criticise or to back his ideas. I do not want to go into the debate on the validity or not of his main tenets, since that would lead to the writing of several books, but just want to point out Freud's main idea, that of jokes allowing human beings to break those social and moral chains that oppress them. Freud pays special attention to what he calls the tendentious jokes and the way in which they can be used not only to express morally unaccepted desire, but to criticize those in power: "The joke then represents a rebellion against that authority, a liberation from its pressure" (Freud 1991: 149). At other times the disguised aggressiveness of jokes is not aimed at people, but at institutions, moral or religious dogmas and ideas or views of life which enjoy great respect. Freud calls these jokes "cynical" and explains how they defend man's right to have his own desires and wishes in a ruthless and rigid moral climate: "So long as the art of healing has not gone further in making our life safe and so long as social arrangements do no more to make it more enjoyable, so long will it be impossible to stifle the voice within us that rebels against the demands of morality" (155). Other scholars have merely focused on the way in which humour reflects the ambiguities of human existence. Thus, Randall Craig in The Tragicomic Novel points out that the tragicomic novel and humour share the same vision of reality and man. For both, the world is not something unified or harmonious, but contradictory and paradoxical, and man participates in this ambiguous character, since he is composed of contrary qualities that he is composed of contrary qualities that cannot be separated.

In The Comic Vision in Literature, and departing from William Lynch's general theory of comedy in Christ and Apollo: The Dimensions of the Literary Imagination, Edward L. Galligan argues that comedy embraces the analogical mind that celebrates the irregularity and diversity of human existence, but is hostile to the univocal mind which tries to reduce reality to abstract generalisations and something mechanical and ordered. Comedy is capable of looking at situations from more than one perspective and it must be admitted that it "takes some gift for wishing to maintain acute double vision in contradictory circumstances, which are the circumstances most of us live in" (Galligan 1984: 34).

The Swiss dramatist Friedrich Dürrenmatt and the writer William Gerhardie, more in the line of Sypher, have stated that comedy is the only genre capable of reflecting the absurdity and hopelessness of the modern world. Whereas Dürrenmatt says that comedy alone is suitable for a society that is terrified by the atom bomb (cit. in Palmer 1984: 132), Gerhardie goes even further when he states that humour is "the most serious quality in literature” (cit. in Craig 1989: 100), since it is capable of recognizing and accepting the concatenate and chaotic nature of modern experience.

Interestingly enough, humour is a subject that in the last decades has fascinated psychologists and psychiatrists. They have been interested in the effect of humour on mental health and, more precisely, in the way it may be used for therapeutic purposes. Much has been written on the subject and I will not try to summarize it all, but it is very revealing for the purpose of this paper to point out how some well-known psychologists, such as Walter E. O’Connell, Harvey Mindess or Victor Frankl, have defended the idea that patients can better cope with their problems if they are capable of perceiving their ironic dimensions, and accept themselves if they are willing to admit their own absurdity. Once again, then, humour is associated with the celebration and recognition of existential paradoxes.

At Swim, Two Boys (2001), by Jamie O’Neill, tells the love story of two sixteen-year old boys, Jim and Doyler. The setting is Dublin 
and covers the years 1915 and 1916, two vital years in the history of Ireland, culminating in the Easter Rising. In "Pal o' Me Heart” David Halperin explains that O'Neill is following the path already taken by other gay male writers in the last fifteen years in his attempt to write a novel not only concerned with male homosexuality, but also with a particular moment in the history of Ireland. He further argues that O'Neill in At Swim, Two Boys is crossing "the codes of Irish identity and gay identity, making each into a figure for the other, thereby producing at one stroke a gay genealogy of Irishness as well as a specifically Irish image of male homosexuality - a romantic vision of the gay male world as 'a nation of the heart'” (2003: 32). Both Irishmen and gay men are looking for their selfdefinition, for their own nation, for their own independence, and it is precisely this search which is described in the novel. Halperin adds that O'Neill is concerned not only with portraying the lived experience of gay desire at that time, but also with the "enduring erotic and political realities" (32).

Joseph Valente expresses herself in similar terms in "Race/Sex/Shame: The Queer Nationalism of At Swim, Two Boys". According to Valente, the novel interweaves two coming-of-age tales, one related to the young protagonists, Jim Mack and Doyler Doyle, and the other related to the Irish nation itself: "At Swim, Two Boys thus sets forth a narrative parallelism that invites its readers to consider the historical, political, and ideological affinities between dissident sexual identity and ethno-colonial identity in an Irish context” (58). O’Neill wants to extend or "resignify" the notion of queer nation: "the articulation of an Irish nationalism that, far from reifying some ethnically proper spirit, orientation, or form of life, would fulfill the queer mandate of instituting 'an oppositional relation to the (social/sexual) norm' or 'resistance to the very idea of the norm as such"' (59-60). The novel establishes an ethico-political parallelism between decolonising or becoming fully Irish and queering or standing outside the norm. Valente explains how this resignification of queer nationalism is done from both the point of view of form and content: "That is, At Swim, Two Boys is not only a historical novel that glosses the Irish struggle for independence in a queer, and queering, light; it is also a literary historical novel that re-imagines the concurrent tradition of Irish modernist fiction as pointing the way to the very sort of re-signifying intervention O’Neill performs" (63).

Thus O'Neill's vision of a nationalism that rejects any normative forms of Irish identity finds its support in the literary heritage of Irish modernist fiction which, according to Valente, takes the condition and expression of shame as one of its main sources of social imagination. Although for different reasons, both homosexuals and the Irish were defined as shameful and this institutionalised shame constituted their common experiential ground. Valente concludes that for O’Neill "the only good nationalism, nay the only Irish nationalism, is a queer nationalism” (82).

John Brannigan has also emphasised the way in which O'Neill "queers" the Rising. Brannigan explains how Roddy Doyle in A Star Called Henry and O'Neill in At Swim, Two Boys revise and re-invent the historical imagery of the 1916 Easter Rising in order to reflect contemporary social and political problems and thus "articulate dissidence from the bankrupt ideologies of nationalism at the end of the twentieth century" (120). But although both writers revisit the social and political conflicts at play in Dublin 1916, O'Neill is much more concerned with rereading the gender and sexual politics of the revolutionary movement: "The novel reads in the iconography and discourses of 1916 nationalism a sublimated celebration of the homosocial and homoerotic" (127). The novel not only explores the theme of homoerotic love being noble and beautiful, but uses the pure and admirable relationship between Jim and Doyler to analyse a series of other relationships -between Mr Mack and Mr Doyle, between MacMurrough and Scrotes, between Gordie and Nancy, between Pearse and his boys, between Eva MacMurrough and Roger Casement- and to show how conflicts and wars are not about struggling for abstract ideas but about men and women fighting for each other or, in some cases, expressing their love through comradeship: "At Swim, Two Boys thus reads the Rising, and the abstracted ideals of nationalism, loyalism, and socialism as forms of love" (131).

The emphasis that Halperin places on O'Neill's concern with the building of a new 
nationalism and the portrayal of the political background of the age, and Valente's and Brannigan's contention that the Irish author is revising the social and political aspects of the Easter Rising, are of real interest to me, because I believe that one of O'Neill's aims in the novel is to demystify one of the crucial moments in the history of Ireland by means of the subversive and liberating power of laughter. I will not focus on the queer meaning of the text, but on the way in which O'Neill exposes the contradictions and absurdities of the Rising and unmasks the fanaticism and dogmatism of the revolutionaries. In order to undermine the heroic vision of the insurrection and the months that preceded it, O'Neill has created a series of characters, Anthony MacMurrough, his aunt Eveline and Mr Mack, to offer us a different perspective of the political milieu of the time.

Anthony MacMurrough is a lonely and sad figure who has found shelter in his aunt's house after having been in prison for two years, sentenced to hard labour for indecent behaviour with a chauffeur-mechanic. But in spite of having been released, Anthony knows that society never forgives people "like him": "At the open window he watched the sea and he saw himself a snail at its shore who carries not his home but his prison with him" (182). He knows very well that "it's not the doing, it's the being that's my offence" (327). Sometimes he despises himself for his homosexuality and calls himself an "ugly sod", whereas on other occasions he is capable of laughing at the labels that "decent people" put on gay men: "Sinners, old man, said MacMurrough laughing. Habitual degenerates in the making" (277). Once he even goes so far as to openly challenge accepted moral values and defend the idea that homosexuals are not perverted human beings, but people with a nature of their own and the right to exist and be respected. Thus, when an old friend of his accuses him of having a flaw in his character and compares him to Oscar Wilde, MacMurrough, with great pride, answers: "If you mean am I Irish, the answer is yes"2 (309). He regrets that no adult told him the truth about the soldiers of Thebes when he was a child, because then he would not have felt the sense of guilt, loneliness and sadness that he experiences now: "Listen, boy, listen to my tale - thought to tell me the truth. Listen while
I tell you, boy, these men loved and yet were noble. You too shall love, body and soul, as they; and there shall be a place for you, boy, noble and magnificent as any. Hold true to your love: these things shall be" (607-8). His only desire in life is to feel good just for once and he really achieves his aim when he decides to help Jim and Doyler build "a nation of the heart" ${ }^{3}$ (329), a "happiness whose consummation must inevitably dash any hope of his own" (433), because Anthony is in love with Jim, a love he has decided to suppress in order not to destroy the beautiful relationship between Jim and Doyler. ${ }^{4}$

But this man for whom life is mainly suffering and pain, possesses a sense of humour that allows him to distance himself from his predicament and see the absurd side of it. It is precisely this detachment with which MacMurrough is capable of looking at reality, which allows him to be aware of the contradictions and absurdities of the Easter Rising and its protagonists. One the main "sources of inspiration" is his aunt Eva, a fervent supporter of Irish independence,

\footnotetext{
2 Valente considers that MacMurrough's answer clearly establishes the link between Irish national identity and queer sexuality: "With MacMurrough's final decisive retort, the mounting coordination in this episode of sexual and ethno-national identityformation, sexual and ethno-national abjection, sexual and ethno-national deviation from the hegemonic norm suddenly slides into figurative identification; where one logically anticipates a homosexual reference, MacMurrough substitutes, with the conjoined violence and aptness of a metaphysical conceit, the term Irish” (69-70).
${ }^{3}$ For a detailed analysis of the love relationship between Jim and Doyler see “A Star Called Henry and At Swim, Two Boys: The Deconstruction of the Tragic Paradigm”, by Aída Díaz Bild.
${ }^{4}$ Brannigan has explained how the love between Jim and Doyler allows MacMurrough to overcome his feelings of guilt and shame by offering him "the model of a beautiful, venerable homosexuality to which he can aspire” (128), whereas Valente has pointed out that it is only when MacMurrough realizes that behind the young protagonists' desire to participate in the revolutionary process is the urge for social inclusion or, in other words, the need the escape from shame, that he decides to "assist the nationalist struggle in achieving this new ethno- sexual symbiosis.” (79)


who, like those obsessed with certain ideals and values, can only see life in terms of black or white, good or bad. We find a very fine example when Eva walks in the garden with her nephew and on commenting that flowers bloom later in Ireland, he answers:

'This is Ireland. Everything comes later here.' She sighed. 'Yes, this is poor old sold-out Ireland.'

Even the late blooming of flowers, apparently, could be laid at the union with England' (192).

Through the use of humour here O'Neill wants to show that fanaticism does not allow people to see reality as it is, but only from their own perspective, thus making them liable to make foolish statements like this one by Eva, who believes that England is responsible for everything that happens to Ireland. MacMurrough knows that life is not just a set of dogmas or ideals and that is why he cannot avoid subverting his aunt's exaltation of Irish past, when he asks her why she drives so often up to the mountains:

'The mountains,' she answered, 'yes. Whence
the O'Byrne' and O’Tooles, our tributaries,
harried the Dane, and Art MacMurrough
Kavanagh, of undying fame, descended on the
Palesmen. Whither the boy O’Donnell fled
from his Castle captors, where Fiach Mac
Hugh swore his word. They held out longest
there, the insurgents of '98. They hid him
there, poor Robert Emmett. There Parnell first
looked upon the land of Ireland, there the
Fenians blundered in the fog. Over the
mountains I go, over the military road.'
It was futile his pursuing the matter...He
remarked, 'It seems a signally busy road.'
(253)

MacMurrough knows that there is not just one reading of the past and that those heroes who have played a major part in it were not godlike figures, but fallible human beings. In other words, he is denouncing how dangerous it is to worship men and women for their deeds.

Of course, MacMurrough's detachment when analysing the Irish insurrection derives from the fact that he is not at all involved in the event. He feels close to that Ireland that symbolises at the same time freedom and sadness and he is proud of being Irish, but does not want to get trapped in risings or revolutionary ideals. If he decides to participate in the rebellion it is merely because of his love for Jim: ${ }^{5}$ "See, I come to war because I love that boy. See how beautiful he is, see how fine. Here is his friend: he too is fine and beautiful. They go to war because they love, each his country. And I too love my country" (630). This explains why when his aunt announces to him that the men have elected him captain of the Irish Volunteers, he just considers the whole situation preposterous, being aware of the fact that "the men had not elected him, no more than he had volunteered" (444). Naturally, becoming a captain of the Irish Volunteers was a great honour at that time and Anthony's not attaching any value to it, helps undermine people's glorification of positions of power during revolutionary periods.

MacMurrough also demystifies the sentimental halo that usually surrounds all kinds of rebellion. Thus, when Eva's car, which carries German rifles for the rebels, is going to be checked by the police: "Hopefully he threw a rug over the boxes. They looked like three boxes of rifles with a rug on top" (488). And when MacNeill announces in the newspaper that the Rising has been cancelled, and Doyler angrily states that "Whatever about that, it's gone off half-cock" (615), MacMurrough cannot help thinking that:

Well, of course it has, MacMurrough thought to himself. It wouldn't be an Irish rebellion else. There had always been something whimsical, even Punch-like, about Ireland at war. One thought of Emmett, the handsome romantic, and his long-laid plans confused by a riot. Of the Young Irelanders whose Tyrtaean anthems and Phillipic gush could rise no further, push coming to shove, than the Battle of Widow McCormack's Cabbage Patch. Of the Fenians, when the rebel force, numbering some hundreds, finding itself lost in the fog, surrendered to a dozen astonished constabulary; their captors then precluding any escape by the ingenious expedient of removing the men's braces. A nation so famously seditious in song, so conspicuously inefficient in deed: it was only the comic that redeemed her (615).

\footnotetext{
5 Valente considers that MacMurrough's initial disdain for politics together with his quasiaristocratic descent, his intellectual élitism, his living with his aunt as a parasite, and the disappointment his aimlessness causes her, links him to the character of Laurence Fahrquahr in Bowen's The Last September and thus casts a reflective light on Fahrquahr's quiet sexual ambiguity.
} 
I think that this quotation is very interesting, not only because it shows a realistic and not idealistic version of Irish past, but because it makes reference to an element that has been vital in the lives of the people of Ireland and which has allowed them to transcend the different painful situations they have been through: humour. This same humour pervades much of the fiction written by Irish writers. In this sense it is very revealing that in his book A Star Called Henry Roddy Doyle also uses humour to offer us a subversive reading of the process of Irish independence that starts with the Easter Rising of 1916 and culminates in the Anglo-Irish War of 1919.

MacMurrough is also aware of the incongruities that are involved in any military revolution. So, whereas a few men are fighting for the independence of Ireland, others have decided that the main focus of interest is not in the centre of Dublin, but in the Royal Spring Show: "Go damn this country, would it never make up its mind?" (616). As a matter of fact, the day of the Rising was a Bank Holiday and most of the people, including the British authorities, who believed that the insurrection had been cancelled, went to the popular races at Fairyhouse (Kee 2003: 159-60).

O’Neill also uses MacMurrough to laugh at the way in which military men tend to cover the truth by giving explanations that really do not clarify anything at all. So, when MacMurrough asks the rebel officer about casualties, the 'reasonable' answer is:

'Ask yourself this,' the officer replied: 'threefoot trenches and the crack of dawn machineguns spewing from above.'

MacMurrough exchanged glances with Doyler, each asking of the other the solution to this conundrum (625).

MacMurrough is aware of the fact that this officer, who is so proud of his rank and position in the revolutionary army, is probably nobody in ordinary life: "Clerk, copyist, penrepairer, some blind alley his talents would never be recognized" (626). Again, O'Neill is bringing revolutionary figures down from their pedestal, showing that there is nothing special about the protagonists of the insurrection, that they, like the rest of humankind, are defined by their limitations and follies. O'Neill further exploits this aspect when the officer says that the women who are insulting the Irish soldiers should return to their kitchens and their spinning: “ 'Spinning,' said Doyler in
MacMurrough's ear, 'where does he think they're out of?'”' (627).

O’Neill also uses MacMurrough's detachment to ridicule politicians and the role they played during the process that led to the independence of Ireland. Anthony is talking with Kettle, a friend from school, and now a member of the Parliamentary Party and, therefore, in favour of Home Rule. During his conversation with MacMurrough about the future of Ireland he does not stop drinking, which makes MacMurrough think: "He recalled the Spartan custom of inebriating slaves that young men should see how contemptible was drunkenness. Nowadays we leave it to our leshishlashors” (306). And when Kettle, getting more and more inspired, and more and more solemn, declares that the three priorities of the Parliamentary Party are "Our land, our learning and our legislation. The three Ls, I like to call them, after the three Fs of your grandfather's and my father's time" (308), MacMurrough cannot but remember that these three "Fs" stood for feast, a fuck and a footrace. Politicians have the same drives and appetites as everybody else and behind their beautiful speeches there is very often just the greed for power and no real concern for people's situation. As a matter of fact, Kettle is the one who despises Anthony for the "flaw" in his nature, incapable of appreciating other realities or nations than the one he wants to build.

But the moment when MacMurrough becomes most irreverent towards the revolution and its protagonists is when in front of Father Taylor, a staunch supporter of the Gaelic League and the independence of Ireland, but, of course, not so liberal as to defend the gay cause, he vindicates in a covert and ironic way the figure of Oscar Wilde. ${ }^{6}$ The whole conversation is truly comic, because Father Taylor thinks that Anthony is talking about a martyr of Irish nationalism and not a man he despises. I cannot reproduce the

6 Brannigan and Valente have stressed the significance of Oscar Wilde in the novel. According to Valente the spectre of Oscar Wilde is the predominant historical presence haunting the novel. In his own time he was the symbol of both Irish eccentricity and homosexuality, "the prototypical ethnic-erotic queer" (58), and in our time he is a patron saint of the critical activist movement Queer Nation, whose main tenets are shared by O'Neill in the novel. 
whole dialogue, but I think an extract of it will illustrate the tone of the conversation:

'I need hardly tell you, Father Taylor, of the desertion by his friends, of witnesses bullied and corrupted, of the agitation against him got up by the newspapers.'

'It was ever the Saxon sneaking way.'

'His conviction was inevitable. But from the dock he gave a celebrated speech that defied to the heavens the traductions of his adversaries.'

'A speech from the dock! I have heard it said, and have said it myself, the speech from the dock is the only truly Irish drama. Three patriots may not gather but a rendition of Emmett or of Tone will edify the occasion. It is a form peculiarly suited to the Irish temperament...' (437)

Maybe, as David Halperin has argued, O’Neill is confusing here Irish nationalism and gay nationalism, but I really think that this passage and others that are similar in content, have a more universal reading. O'Neill is criticizing and ridiculing the fanaticism and dogmatism of all revolutionaries who are only capable of seeing reality in terms of white or black and for whom everything or everyone that does not fit into their patterns is bad and therefore should be eliminated. Because of his inflexible outlook on life Father Taylor cannot understand that for gay men like Anthony the real martyrs are not the traditional heroes of Irish past, but figures like Oscar Wilde, who incarnates the suffering and pain most of the homosexuals experienced at that time. In this case the ludicrous element is exaggerated by the fact that Father Taylor, like most of the characters in the novel, rejects homosexuality and thus his support of MacMurrough in his exaltation of Oscar Wilde, without knowing it, makes him a figure of ridicule.

If Anthony is used by O'Neill to subvert some of the apparently heroic moments and aspects of the Irish insurrection, his aunt, Evelina MacMurrough, Eva, becomes an incarnation of the contradictory nature of human beings and a vehicle to undermine the figure of the patriotic rebel. Through her O'Neill shows that people are not easily classified as right or wrong, saints or sinners, nor are circumstances ever merely black or white, and that all claims to unquestionable truth and goodness, or, in other words, to godlikeness, are just chimeras.
And, of course, the weapon used by O'Neill to point out the ambiguities of human nature and patriotism is humour.

Eva is in a sense a feminist, a strong defender of women's rights in an age when most people believed that their place was at home. For her the word "bazaar" is a dread one because it perfectly symbolizes the passive, decorative and "ladylike" role that men expect from her during the preparation of the revolution:

Not for the first time she wondered what she wanted with this priest. Of course, it was her name that he was after, that illustrious and priceless name, on the headed notepaper of one more committee, her gloved hand opening yet another bazaar. How tedious it all could be. One yearned for the grinding of pikes on a stone, but the reality for a woman was tea parties, muffin fights, hearts sunk in raising lucre (119).

She knows that laws are unfair to women, always absolving men from the injuries caused to females. She is also aware of the fact that many of the stereotypes of women derive from their submissive role in life: "He regarded women as practical, she told him, because he never saw the sex but it was tending to his needs: bringing his tea, making his fire, paying his cigarist's bills" (593). She has learnt that existence is even harder for a spinster like her, especially if she decides to get involved in an 'unladylike' event such as a rebellion. She can only have the whole respect of the community if she has a man by her side. That's why she is so eager to be seen in the company of either Father Taylor or her nephew: "But a spinster of the parish, of whatever means or dignity, has little sway without a priest at her side” (302). She would like to participate more actively in the war and be treated like any of the other male rebels, but this domain belongs only to men: "It was a preserve she had struggled all her life to touch, yet never had reached. Nor had any woman touched it, Kathleen nor Rosaleen nor the Shan Van Vocht, for all their summons and goad" (543).

And yet, she tries to overcome all these limitations that are imposed on her and perform an active and useful role in the Irish revolution. As a matter of fact, she believes that women have been fundamental throughout the history of Ireland and, thus, when the Aud, the German ship carrying arms and 
ammunition for the rebels is intercepted by the Royal Navy, her indignation makes her attack the inefficiency of men in opposition to woman's competence. The quotation is worth reproducing because Eva's anger gives the whole passage a comic tone:

\begin{abstract}
'They muck bloody up. They couldn't get the arms to the beach even. These are the men who refused any assistance. A woman's use is a nurse and typewriter. Have they never looked at their wives? Have they not seen their mothers? They might try managing a household on these novel lines. We should have lunch for supper and come home without the kiddies. One wonders what they hope to do with the Poor Old Woman, after they have toasted her in exotic beverage. Throw her to the kitchens with the praties?' (513).
\end{abstract}

Because Eva does not want to be just another "Angel in the House", she tries very hard to get involved in the historical events that are shaping her age. She goes to London for the Coronation demonstration of 1911 and is taken to prison for marching with the Irishwomen's Suffrage Federation. Thanks to her brother's influence she only stays three quarters of an hour in the cell, but her nephew knows that she would have liked to have stayed longer in prison and start a hunger strike. She also participates in the 1913 Lockout, helping the workers, although she is only allowed to be in the kitchen, a woman's place, which must have been very annoying for her. And when the Rising is approaching she barters half her jewels and all her influence to get some rifles for the Irish army. She is never afraid of the consequences of her actions: "But dangerousness as a subject did not interest her" (442). MacMurrough knows that if she had not been incarcerated in the Castle when the Rising started, "She'd have taken the Shelbourne, yes she would, with just her Webley a-wobble in her hand, and there'd be none of this nonsense of entrenching a park.” (630). Naturally, her death matches her life: "She was slumped on a Castle balcony, her death-face grim and ghosted still with exhilaration. Shorty lay beside her, though whether he had given his pistol for her to fire, or she had seized it from him,...” (641).

But this woman who is apparently so advanced for her times, so liberal, so much against any kind of discrimination, cannot get rid of her social prejudices and it is precisely this contrast between her ideals of freedom and her certainty, as her nephew says, "of her standing, in history and in place” (191), of which she is not aware, that generates humour in the novel and helps offer a more human picture of a revolutionary figure.

It could be said that Eva is a very unusual rebel with a very original view of the revolution. She believes that people of 'her standing' are born to lead, to show the path to others. Obviously, she thinks that her way is the only one and that, although people think that the revolutionaries are malign and pernicious, “...One does not despair, however. One knows that should sufficient change their minds, one will be a good and honoured prophetess. One therefore decides those minds shall change” (256). MacMurrough cannot but smile at his aunt's reasoning: "'I had not thought you so sophistical,' he said. 'That the good and the true should obtain in the opinion of others. You make a democracy of virtue'” (256). Eva's words are very interesting, not only because they reveal the contradictions that define all human beings, but also because they show how the blind commitment to a series of ideals and dogmas does not allow people to see life from more than one perspective and, therefore, they become inflexible and fanatical, something that Anthony with his fine irony is pointing at.

Eva cannot even forget her origins when she speaks about one of the fathers of the Rising, Patrick Pearse. He attends a garden party she celebrates and her description of him cannot be more patronizing and "stylish":

'The funeral is tomorrow. This young man is to give the panegyric at his graveside. He was tempting us with little morceaux choisis on the terrace. How we thrilled. Les fous, les fous, les fous! Meaning the British. The lisp is unfortunate and he has small grasp of oratory, but the words had us all a-tingle.'

'Is the speech to be given in French?'

'Don't tease. One translates for dramatic effect.' (300)

Again MacMurrough is hinting at his aunt's limitations, especially her tendency to play all the time the grand lady. Eva seems to think that it is more elegant to use French words in her conversation and in this case it becomes really ludicrous since she is translating the words that an Irish patriot, Pearse, was to pronounce at the funeral of the veteran Fenian leader O'Donnovan Rossa, an event that became crucial in the process towards the Rising. 
Eva is also quite patronizing towards Father Taylor who, as we saw before, is member of the famous Gaelic League, the aim of which was to encourage the learning of the Irish language, Irish clothes, Irish dances, Irish poets and "every cultural detail that could be found to distinguish Irishness from Englishness was to be sought out and made the inspiration of the Irish people” (Kee 2003: 141).

Although initially the Gaelic League declared itself to be a non-political movement, in reality it became the gateway to political and revolutionary activity. Father Taylor is a staunch defender of the ideals of the Gaelic League and, as a matter of fact, works hard to reinforce Gaelic culture and language in Kingstown while the canon is away. These references should make him the best company for Eva and, nevertheless, she keeps a detached, indifferent and often superior attitude towards him. She gets cross, for example, when the maid brings Indian tea for the Father, because "Minton for a bishop at the very least, any old Davenport for a curate" (118), or she feels relieved when the priest seems to have given up the idea of having the boys playing hockey in her lawns: "I had suggested croquet at a shilling a mallet, but this apparently was not the thing. So difficult when one entertains outside one's circle” (254). She also gets lost or does not pay much attention whenever the priest talks about important things related to the history of Eva's family or the future of Ireland, making ironic comments that generate the reader's smile:

...For the past twenty years the Gael has been crying aloud for help to beat back the Anglicization that drags its slimy length along. The immoral literature, the smutty postcards, the lewd plays and suggestive songs were bad, yet they were merely puffs from the foul breath of a paganized society. Even today I saw ye, many of ye here this morning, on your very way to Mass, I saw ye stoop to purchase (115).

Father Taylor would have been very disappointed if he had known that while he was speaking about serious matters, Eva was thinking that he did not know how to sit properly on a sofa - "Whatever it is they teach in Maynooth these days, she considered, it is never command of furniture" (114) - or wondering what childhood illness had rendered his face so blemished. She is even quite irreverent towards him in her thoughts, since when he presents himself as Father Amen O'Toiler, using the Gaelic 'version', she reflects that his name is "a sermon in itself" (28). And on descending the stairs to meet him, she has to restrain herself from exclaiming in a playful way "Forgive me, Father, for I have sinned" (113). As she says to herself: "Stop it, now, one must be sober" (113).

These thoughts and comments that make the reader laugh are more profound than they may seem. It is true that Eva feels socially superior to Father Taylor, or Father O’Toiler, as he prefers to be called, but it is also clear that her indifference and sometimes ridiculing stance towards him stems from her awareness that if a section of the Church, which has always had a powerful influence in Ireland, is now on the side of the rebels, it is not because they firmly believe in the revolutionary ideals, but because they, as usual, want to be on the side of the winners: "If this now was the teaching of seminaries, change most certainly was in the air" (29). This explains why she hardly listens to Father Taylor when he praises her family, of which she is ever so proud. She knows that he only wants to flatter her to get her support. Thus, when the priest in his false exaltation of Eva's father says that he has seen many painted windows in chapels with MacMurrough's name in dedication, Eva, instead of being overwhelmed by such an eulogy, reacts in a very cool and realistic way thinking that "Yes...her father had been scrupulous in providing for the Church. The rate of one glass window per bastard born, if she did not mistake" (117).

There is a last aspect of Eva's contradictory personality that O'Neill fully exploits to introduce humour in the novel. It is Eva's attitude to homosexuality. I will not go into detail about this topic, since we are dealing here with O'Neill's subversive reading of the process of independence, but there is a moment in the text that brings Eva's notion of homosexuality and politics together. Eva, who believes that there should be no sexual discrimination, that men and women should have the same rights, and that Irish people must possess their own country, denies that possibility to homosexuals. She thinks that homosexuality is a phase men go through and that once it is over, people like her nephew come back to society and start a normal life by marrying and finding employment. She 
innocently believes that a gay man can be compared to any other 'criminal': because you have stolen once, this does not transform you into a thief for ever. This explains why she gets so disappointed when she finds out that "it is not over", that her nephew, who she thought was now on the "good path", still feels attracted to other men. But, although she despises homosexuality and believes that her nephew's idol, Oscar Wilde, is just a buffoon, she cannot but congratulate Anthony when, after saving Sir Edward Carson, he kisses him on the lips:

And MacMurrough had laughed like a schoolboy, and he heard now his aunt was laughing too.

'You are a wicked, wicked boy,' she said, 'and the Lord knows what retribution may come. The Attorney-General. King Carson himself. You gave your name?'

'Naturally. I am a gentleman.'

'Oh, quel beau coup pour l'Irlande!' And she gazed upon her nephew with fondest affection. She took both his hands in hers. 'What a wonderful boy you are. And I did love you so and I do love you still.' (441)

We have to remember that Edward Carson was the lawyer who represented the Marquis of Queensbury against Oscar Wilde and, therefore, Anthony's reaction is quite normal, a kind of revenge for what Carson had done to "one of ours". But Carson was also the champion and leader of the Ulster cause and that is why Eva is so excited about her nephew's punishment of Carson. Eva's reaction is obviously ridiculous, since she, who does not accept the reality of homosexuality, is congratulating Anthony for having exposed his homosexuality in public. At the same time, she is so enthusiastic about the whole episode, that she does not seem to be aware of the consequences it may have for Anthony, showing thus once again that the commitment to ideals and principles not only make us blind to the rest of reality, but transforms us into figures of fun.

If Eva represents better than any other character in the novel the contradictions that define human beings, Mr Mack, Jim's father, reflects the absurd and often ridiculous situations that a political situation may generate. Mr Mack is a shopkeeper who wants to climb up the social ladder. As he is always saying to his son: "We're on the up, Jim, never forget it" (38). That is why he does not want his son to be seen in the company of shop-girls or maids and is obsessed with polishing his son's language, sometimes creating funny situations. Thus, when he asks his son to deliver some advertising-bills and the boy by mistake uses the word "distribute": " 'Deliver them.' Though in point of fact, distribute was probably the more appropriate sentiment in this particular instance. Fair dues. Comes from having a scholarship boy for a son. 'Distribute them if you choose...' " (38).

This man who prefers to be called 'Papa' rather than ' $\mathrm{Da}$ ' because it suits better his social category, is also wholly devoted to the British Army, to which he belonged for a time as a Royal Dublin Fusilier. He has very good memories of the army: "He might mention three square meals a day, smart uniform, healthy living, separation money for the women at home, pension at the end of it. Satisfaction of fighting for King and Country. Glory to be had and to spare. Travel far and wide.” (48-9). He, who was an orphan, found shelter in the military forces, which "took me in, fed me, clothed me, made the man I am today" (55). And not only is he proud of "the finest-trained and best-rigged army the world over" (55) and spends most of his spare time polishing his medals, but is glad "to be a part of it, this great empire at war" (55). He is also always reading the newspaper for the latest news on the European war. Nevertheless, his patriotism sometimes does not allow him to see things in an objective and detached way, but in a distorted one, thus generating comments that are truly comic. We have a very good example when he goes to Dublin and sees that a shop has Turkish Delights on display: “...I was that shook. It was all I could do not to lob a brick through the glass. They have no respect some people, no cop-on at all” (354). Naturally, the sweets are not responsible for their name or what the Turks are doing to the British in the war, but Mr Mack's vision of the conflict is so monologic, to use Bakhtin's term, that he is incapable of realising the absurdity of his thought. Something similar happens when he tells his son Jim that the kind of embroidery Aunt Sawney does, called Berlin-work, "ought not to be entertained during the current hostilities" (420).

Obviously, this staunch defender of the established order rejects anything that smells of revolution. When he hears someone calling Doyler a Larkinite, referring to the worker's 
movement initiated by James Larkin and James Connolly and which culminated in the foundation of the Irish Citizen Army, to which Doyler belongs, he is deeply shocked, because "Wasn't that an agitator of the blackest variety?” (50). Of course, Mr Mack, who is loyal to the "King and Country" believes only in the official truths told by those in power and that is why for him Larkinism and socialism only lead to disruption and chaos. This is clearly seen when Jim, who has been talking with Doyler about socialism, asks his father what this word means for him:

'Socialism means Larkinism and Larkinism means all ballyhooly let loose. Do you not remember them strikes we had and oratating in the street? Bully-boy tactics is all them fellows knows. And trying to send poor Catholic children to Protestant homes in England? That was beyond the beyonds.'

'Only so's they'd be fed.'

'What's that?'

'They had no food, Da. The children didn’t.'

'If they had not food why wouldn't they go back to work? Stands to reason.'

'They were locked out sure.' (130)

Mr Mack does not want to accept the version of the 1913 Lockout that Doyler has told Jim, but which was the true one. The real and sad truth was that in response to the general strike called by Larkin, Dublin employers decided to close their businesses, locking out the workers and making them and their families suffer great hardship. Some good English people offered to take care of the children of the Irish strikers during the winter of 1913-14, but they were prevented from doing so by a group of Catholic parents and priests. In this sense, $\mathrm{Mr}$ Mack is a clear example of how dangerous it is to get trapped in the net of principles, because it does not allow one to have an open and flexible outlook on life.

But Mr Mack, the real incarnation of British patriotism, soon discovers that political upheavals may distort your life completely and create absurd situations which you are not capable of controlling. He is so loyal to the Crown and the British Army that when he realises that one of the recruitment posters is coming away at the edge, he tries to fix it with "terrible" consequences for him, that O'Neill handles with great mastery and humour. A constable sees him trying to put the posters right, but instead of congratulating him for his patriotism, takes him to the police station because he thinks he is just one of those revolutionaries who tear down posters as a way to express their rejection of recruitment. The poor Mr Mack is so overwhelmed by the situation, that the explanation he gives to the constable cannot be more ridiculous: "In a low voice he explained, over and over again, that the glue-merchants and paper-manufacturers were all to blame and truth be told were in league with the Kaiser" (111). But the worse thing is not that his name appears in the paper, but that people start distorting the whole event:

Rumour soon had him flootered to the eyeballs, cursing melia murder and clawing at posters till his nails were raw and his fingers raddled with blood. Six peelers it took and a superintendent to hold him down, frog's march to the station and him bawling roaratorious and abusing the poor polis, seed, breed and generation of them, for Castle whores as sold their soul to England (144).

The quotation is really comic because, knowing Mr Mack, nobody would expect him to behave in such an unpatriotic and wild way, and serves O'Neill not only to satirize the way in which people tend to distort events, especially in times of political disorder, but also to refer indirectly to all those rumours that circulated in Dublin in the days prior to the Rising and which very often were just daydreams.

Mr Mack's "little misunderstanding" also helps O'Neill criticise the Church and its lack of humanity, a common trend throughout the whole novel, as well as the inflexibility of those who are obsessed with their own ideals. Mr Mack is so desperate that he decides to go and visit Father Taylor, thinking that because of the Church's powerful influence, the priest may be able to help him. But Mr Mack makes a great mistake: in order to clarify his loyalty to the Crown he wears his medals, not knowing that Father Taylor is on the side of the rebels:

'Ribbons, gongs, stars. There is a species of ant in the tropical forests -you may have read it in the Missionary Annals- that captures the eggs of a rival nest to rear them as soldiers of its own. These soldiers are renowned for their curious loyalty.'

Mr Mack detected a former footing and warmly he said, 'It is the Irish Catholic we gets at home, Father, and we reads it every Friday by the fire together. Prior, that is, to saying the Rosary. That and the Messenger of 
the Sacred Heart. But if your reverence would recommend the Missionary Annals I'll be happy to subscribe' (165-6).

Mr Mack's reaction is comic because he does not understand the symbolic meaning of what Father Taylor is saying, but serves also to denounce the rigidity and lack of humanity of a priest, who instead of feeling pity for a man's suffering and being concerned with his soul, despises him because of his political ideas. His inflexibility and incapacity to accept dogmas other than his own also becomes obvious when Mr Mack starts apologising for what he did with the posters and Father Taylor, to $\mathrm{Mr}$ Mack's astonishment, changes his attitude and congratulates him for being an Irishman. The whole situation is comic because of Mr Mack's inability to understand Father Taylor's comments and changes of mood, but it is obvious that behind this humorous façade there is a strong denunciation of an institution, that above all and despite all political controversies, should love all men equally.

But, 'miraculously', the accident with the poster puts Mr Mack on the up again. Due to Father Taylor's influence, Mr Mack's life changes for better. Not only is he giving the tuppenny collections at chapel on Sunday and becoming a member of the Mary Immaculate Traders' Guild of Glasthule, which for him are two great honours, but is asked by the priest to instruct the band of boys he has created in order to cultivate the Irish language and culture. The situation is really hilarious, because the priest with his obsession to make the boys familiar with the Gaelic language, wants Mr Mack to speak Gaelic to the youngsters, something that the poor man has some trouble with:

The priest had insisted the commands should be gave in Gaelic and his poor father could never get his tongue round the alien sounds. Quick march came out: Gum on my shawl! Right turn was: Arrest young piggy! Shower of gigglers, his father complained. Jack-acting and jig-acting in the ranks. But if he called a boy out, he must call him at the double, and that dread command off his father's tongue was: Erse sodder! And his father's tongue would taste his moustache in puzzlement at the scurrility it spoke (224).

And the worst thing is that in spite of $\mathrm{Mr}$ Mack's efforts during the drills to look like an Irish patriot by wearing a green sash, he is just the picture of an Orangeman. But behind the comedy that pervades the whole scene there is once again a denunciation of those who try to impose their ideas and obsessions on others. It does not matter whether your principles are more liberal or revolutionary than those of others; once you try to force the rest to adapt themselves to your moulds, you are curtailing their freedom.

Mr Mack's desire to have the favour of the priest as a means of avoiding prison also creates funny situations, as, for example, when Aunt Sawney, in front of the priest, says that the Irish Volunteers are "idle blaspheming rebels” (232), and “Jim's father has to dash out with a half-crown donation to the cause of buying Chinese children to convert them to the Cross” (232). Mr Mack's response generates the reader's smile, but is also a clear reminder of the humilities that many people have to go through in times of political and social disruption in order to save their skin.

But just when Mr Mack thinks that all has been cleared up and things are improving for him, he has a second "misunderstanding" with Dublin Metropolitan Police. He is so eager to please Father Taylor in his attempt to recuperate the Irish language and Irish songs, that he is caught by the police with the band singing Irish patriotic melodies outside a Protestant church, while inside the son of a superintendent is receiving his last respects. Again, Mr Mack's innocence -he is not aware of what is going on inside the church- leads him to perform a most revolutionary act. Nancy, the mother of his grandson, cannot but make fun of her father-in-law: "You'll be getting a fierce name for yourself, Mr Mack. Second mention in as many months. Breach of the peace, wasn't it, this time? Likely to occasion? Mind you, that was unfortunate that the poor dead soldier was the son of a superintendent” (247). She knows perfectly well that Mr Mack is a quiet man who would never dream of challenging the established order, but reality is never white or black, but essentially contradictory and absurd and even the greatest patriots can become by chance the greatest traitors. In this sense it is interesting to point out here that in The Spirituality of Comedy Hyers explains that one of the main functions of comedy is precisely to acknowledge the arbitrariness and randomness of our lives:

Comedy has always supported a chaos theory of the universe - not over against order, but as 
a qualification of order and reminder of the presence and importance of these aspects of our experience which we are not always eager to allow. Hence the comic delight in playfulness, spontaneity, immediacy, irrationality, confusion and absurdity (Hyers 1996: 175).

Comedy shows us that human existence is not orderly, intelligible or predictable, but essentially chaotic and irrational. No matter how hard we try to structure our lives and make sense of them, "our lives and our histories still manage to move in mysterious and unforeseen ways" (191). Through comedy we learn that many of the things that happen to us are not the result of some master plan or cosmic design, but the fruit of chance, accident, mistake, decisions of the moment, etc.

Mr Mack's 'heroic' feat becomes wellknown all over Kingstown, to the extent that the boy who is selling the newspapers asks him if he is the General of the Fenians and tells him that he and his friends are willing to fight with him against the enemy: "Only say the word and we're out, Mr Mack. A Nation Once Again.” (242). Mr Mack is totally baffled by the situation and, as a matter of fact, when the boy questions him on his military rank he does not get the real meaning of it and answers back: "Well, I have the general stores above" (241). The whole event is totally comic, particularly because of the contrast between the young boy, who thinks that he is talking to a kind of god, and Mr Mack, who, as usual, is slow to assimilate what is going on. But the end of the meeting is even more hilarious:

The snot sniffed back inside the nostril, then he did a thing never heard of before. Never known to pass in Glasthule parish or any parish in the barony, nor ever in the four fields of Erin, go to that of it. He pulled out a paper and gave it gratis for nothing. 'The Sword of Light is shining still,' said he, then he crossed the road to Fennelly's. 'Final Buff!' came his high-pitched quaver before the doors swung shut behind.

Mr Mack stared after. The scrawl of him to give such scandal. He stroked his moustache, attempting to trace in its hairs the series of events that had led to his being the darling of newsboys. Sclanderous. And all I had wanted was a little respectability. (242)

The contrast between the elevated tone and the content, which is quite trivial, since it refers to the giving away of a free paper, helps introduce humour in this case, a technique which has often been used by writers, such as Jane Austen, to illuminate their works with comic and ironic sparks. On the other hand, the last paragraph makes us laugh because it shows us the ridiculous and absurd side of a situation that has transformed such a conservative and ordinary man as Mr Mack into a martyr.

But Mr Mack's fate changes again when the canon, who has been away because of a bad illness, returns and overturns Father Taylor's work. The canon is a very traditional priest and, of course, does not agree with Father Taylor's more revolutionary ideas. The canon undoes everything Father Taylor had done and this includes demoting $\mathrm{Mr}$ Mack from the sixpenny-door to the tuppenny-door. $\mathrm{Mr}$ Mack's great dilemma in life now is: "If he distanced himself from the curate might he get the sixpenny-door back? Or was it only the curate's patronage got him any door at all?" (351). That Mr Mack's highest worry be how to get back his sixpenny-door when he has so many other things to be concerned about -his son Gordie, who is fighting in the European war, is missing, the police still think that he has broken the law, etc.- works as an anti-climax and generates the reader's smile.

The 'decrowned king' meets again the boy who thought he was the General of the Fenians, but who now knows the truth because his father has explained it to him. He is selling The Workers Republic, the newspaper founded by James Connolly with the aim to "unite the workers and to bury in one common grave the religious hatred, the provincial jealousies, and the mutual distrusts upon which oppression has so long depended for security" (cit. in Tierney 1992: 142). The content of the newspaper is wholly revolutionary, but Mr Mack decides to buy all the copies from the boy because he feels pity for him, working that late at night, thinly clothed and hardly fed. This time $\mathrm{Mr}$ Mack, who is one of the most interesting characters in the novel because he undergoes a gradual transformation, is capable of seeing the situation from a distance and laugh at himself: "He wondered what was he to do with thirteen Larkinite papers. Knowing his luck now a constable would come along and he'd fetch up himself in the cells” (387).

$\mathrm{Mr}$ Mack decides to return to his normal life and former loyalties. He goes to Dublin to talk to the British authorities, because he wants to join the 'Georgius Rex', a group of elderly 
part-time soldiers. But fate again will not allow him to fulfil his role as a British patriot and will make him into a rebel. At the same time that he is looking for Dublin Castle, Eva MacMurrough is trying to drive away from the police with her car full of rifles for the Volunteers. But "someone" interferes with her plans and makes her smash her car into a corner lamppost: "Some bowler-hatted ass stepped into the road. He looked for all the world to be studying the tops of buildings" (489). Naturally, that man is Mr Mack, who on telling the police that he knows that woman, is immediately suspected of having helped her nephew, who was also in the car, escape: "It took the better part of three hours, but $\mathrm{Mr}$ Mack at last found his way, courtesy of the Dublin Metropolitan Police, to Dublin Castle. While he was being led through the courtyard to the DMP office, there to explain why he had aided a fugitive in escaping the law" (490). The use of antiphrasis in "courtesy" and the fact that just when he wants to show his support to the Crown he is again accused of being a traitor, introduces the element of humour and shows the absurd situations which any military conflict may generate.

Mr Mack also helps O'Neill demystify the Easter Rising itself, allowing him to narrate it from a comic point of view. As usual, $\mathrm{Mr}$ Mack is in the wrong place at the wrong time. He is in Dublin when the Rising starts, looking for his son Jim, and since he is totally ignorant of what is happening his reactions cannot but produce comedy. ${ }^{7}$ To start with, he does not understand why all of a sudden people start taking bedsteads, mattresses, etc., out of their houses and blocking the highway. The only conclusion he can reach is that a riot is going on, which explains why he is so puzzled when somebody mentions the word "republic": "What republic?" (559). Mr Mack gets even more confused when people start crying that the Lancers are coming and he, on hearing the discharge, identifies the rifles as Mausers, that

\footnotetext{
${ }^{7}$ It is interesting to point out that many authors tend to tell their stories from the point of view of a clever and observant child who because of his age is ignorant of the world at large, thus paving the way for humour without destroying the essential meaning of the story or making it grotesque. Recent Irish examples are Paddy Clarke Ha Ha Ha (1993), by Roddy Doyle, Angela's Ashes (1996), by Frank McCourt, or Reading in the Dark (1997), by Seamus Deane.
}

is to say, those used by the Boers: "Mausers without a doubt, great blunderbussy yokes of things the Boers had always favoured. But what would the Boers be doing in Dublin?” (560). Mr Mack's reasoning is obviously ridiculous, but again the humour stems from his ingenuousness. Mr Mack was in the Boer war and that is why he knows what kind of information he is being given, reaches conclusions that are far-fetched and hilarious.

So, when he discovers that the headquarters are in the General Post Office, he asks himself: "What on earth would Sinn Feiners want with rifles the Boers used. But what he is unaware of is that in 1914 Roger Casement, Erskine Childers and Darrell Figgis had procured Mauser rifles and rounds of ammunition from Germany for the Irish Volunteers. Mr Mack even considers the possibility of de Wet appearing on the scene: "The Boer War Mausers growled still, and it would scarce surprise him now if de Wet himself appeared at the head of a commando wasn't it always whispered de West was none but Parnell returned?” (560-1).

$\mathrm{Mr}$ Mack has the feeling of being an observer who is watching a spectacle with the detachment of one who has nothing to do with it. This explains why when somebody points at the Sinn Feiners, Mr Mack reacts in a "scientific" way: "“Oh, they're Sinn Feiners," said Mr Mack, peering the better to see these queer near-fabled specimens" (561). This same distance allows him to recognize the comic side of some of the worst moments of the Rising. While he clings to the pedestal of Nelson's Pillar in order to avoid being smashed by the crowd -not a very heroic position- he witnesses the widespread looting of shops and stores. Obviously, there is nothing to celebrate about people stealing goods, but the looting itself had a comic side in the kind of objects that the poor people of Dublin chose to take with them. In Ireland. A History, Kee describes how "One man walked off wearing a dress-suit in the middle of the day, and carrying a golf club" (Kee 2003: 163), and in At Swim, Two Boys, Mr Mack watches how "By him sailed the most fanciful apparitions. A slum-boy in three top-hats swinging golf-clubs. Dirty-faced girls with boas and high-heeled shoes on" (563). The expression "most fanciful apparitions" is mostly ironic since it is clear that a poor boy from the slums will not get much use of a golf club and the same can be 
applied to the girl and her boas.

Mr Mack in his effort to make sense of the information he is being given, reaches conclusions that are far-fetched and hilarious. So, when he discovers that the headquarters are in the General Post Office, he asks himself: "What on earth would Sinn Feiners want with a post office? It crossed his mind in a daft way that they, like him before, had mistook it for a bank.” (563). Mr Mack also acknowledges a fact that was very obvious: the 1916 Easter Rising was not a rising of the Irish people, but planned and carried out by a small group of revolutionary activists: "The Provisional Government of the Irish Republic. To the People of Ireland. Signed then by a poweration of names nor he nor anyone else had heard of" (563). The Rising, as Kee, Tierney and many other historians have explained, was not popular and, as a matter of fact, "the majority of Irish at that time (Easter 1916) were horrified by the whole affair, especially the destruction of the centre of Dublin" (Tierney 1992: 172). When the Rising failed and the prisoners marched through the streets of Dublin, their escorts had to protect them from the abuses and attempts of assault of angry Dublin people.

But, perhaps one of the most important moments during the Rising is Mr Mack's encounter with Father Taylor, who is so excited about what is happening, that "It would scarce have surprised Mr Mack now if the priest had lifted his frock-coat and floated across the road, so strange and elated his countenance" (568). Although this description may generate the reader's smile, Father Taylor's comments are very revealing, since they show one of the ugliest sides of all kinds of wars and revolutions. To start with, Father Taylor manipulates the truth for his and the Church's benefit. The Larkinites are now "good brave Catholic sons of Ireland, who in this final hour had repented their former impieties" (567), a comment that would have made Larkin turn in his grave, since the Irish Catholic hierarchy and many of the Catholic clergy opposed the strikers during the 1913 Lockout. And when Mr Mack suggests that the orange on the republican flag is a generous acknowledgment to the Protestant north, Father Taylor "would assure him that a little Irish weather would soon fade that orange to Vatican yellow. For Mr. Mack was to consider this was indeed a Catholic rising and therefore a blessed one too" (567). But the worst and most dangerous part of Father Taylor's 'sermon' is not his praise of Ireland in detriment of England -"The Saxon tide must trouble no more the sacred shore. Again must Ireland rise, isle of saints and scholars, to shine lamp among the nations." (567)- but his greed for martyrs: "Mr Mack, pray God your son may be so exalted as with these joyful martyrs to die" (568). What Father Taylor is exalting here is what Hyers calls tragic heroism which has always led to the greatest atrocities and crimes: "In the name of duty and loyalty, honor or prestige, God and country, it sacrifices the very people involved on the altar of principle and virtue" (Hyers 1996: 50). Tragic heroism endorses "warrior" virtues: courage, loyalty, duty, honour, pride, stubborn determination, absolute devotion, which can only have destructive consequences. Comedy, on the other hand, focuses on other virtues: flexibility, freedom, compromise, playfulness, lightheartedness, childlikeness, celebration of life, survivability. Comic heroism enjoys and celebrates life and does not try to reduce it to a series of abstract principles:

It is far more concerned with saving skin than with saving face. And its defense is of persons more than principles, the spirit rather than the letter. 'The Sabbath was made for man, not man for the Sabbath' might well serve as a comic motto. The ethic of comedy is situational. Moral codes are in the service of people and their circumstances (Hyers 1996: 66).

And this, I think, is one of the most important lessons of A Swim, Two Boys, a lesson that Mr Mack learns when he becomes desperate to find Jim, who has joined the Irish army. When he is caught by the constables during the insurrection because of his supposed connection with the rebels, no dogmas, no ideals or principles are any longer important to him, but life and the people who are dear to him:

He did not think of canon nor curate, of doors, tuppenny nor sixpenny. Not of Ireland nor Dublin, which both must surely be brought to ruin. His years with the Colours were nothing to him, his regiment might never have been. While the constables marched him away, he stared back up the road where the soldiers had gone, the first of thousands to come, thinking only, helplessly, Jim, my son James, my son, my Jim (624). 
At Swim, Two Boys is not just a romantic story of gay love, but a novel which demystifies the process of Irish independence by using the powerful and subversive force of laughter. The text testifies to the many- sidedness of human beings and the chaotic, random and absurd essence of life, while defiling and questioning an important moment in the history of Ireland.

\section{Works Cited}

Bakhtin, Mikhail. 1984. Rabelais and His World. Bloomington: Indiana University Press.

Brannigan, John. 2003. “'The Battle for the GPO': Literary Revisionism in Roddy Doyle’s A Star Called Henry and Jamie O'Neill's At Swim, Two Boys”. In Kaleidoscopic Views of Ireland. Eds. Munira H. Mutran and Laura P. Z. Izarra. Sao Paulo: Humanitas FFLCH/USP: 115-132.

Chapman, Antony J., \& Hugh C. Foot eds. 1996. Humor and Laughter. Theory, Research and Applications. New Brunswick: Transaction Publishers.

Craig, Randall. 1989. The Tragicomic Novel. Studies in a Fictional Mode from Meredith to Joyce. Newark: University of Delaware Press.

Deane, Seamus. 1997. Reading in the Dark. London: Vintage.

Díaz Bild, Aída. 2005. "A Star Called Henry and At Swim, Two Boys: The Deconstruction of the Tragic Paradigm”. ES, 26, 71-90.

Doyle, Roddy. 1994. Paddy Clarke Ha Ha Ha. London: Minerva. . 1999. A Star Called Henry. London: Jonathan Cape.

Freud, Sigmund. 1991. Jokes and their Relation to the Unconscious. Harmondsworth: Penguin.

Frye, Northrop. 1990. The Anatomy of Criticism. Four Essays. Harmondsworth: Penguin.

Galligan, Edward L. 1984. The Comic Vision in Literature. Athens: The University of Georgia Press.

Gutwirth, Marcel. 1993. Laughing Matter. An Essay on the Comic. Ithaca \& London: Cornell University Press.

Halperin, David. 2003. "Pal o' Me Heart. Review of Jamie O’Neill's At Swim Two Boys”. London Review of Books, vol. 25.10, 32-3.

Hyers, Conrad. 1996. The Spirituality of Comedy. Comic Heroism in a Tragic World. New Brunswick: Transaction Publishers.

Kee, Robert. 2003. Ireland. A History. London: Abacus.

McCourt, Frank. 1997. Angela's Ashes. A Memoir of Childhood. London: Flamingo.

Mercier, Vivian. 1992 (1962). The Irish Comic Tradition. Oxford: Clarendon Press.

Mindess, Harvey. 1996. “The Use and Abuse of Humour in Psychotherapy”. In Chapman and Foot, pp. 331-41.

Morreall, John. 1983. Taking Laughter Seriously. Albany: State University of New York.

Mutran, Munira H., \& Laura P.Z Izarra, eds. 2003. Kaleidoscopic Views of Ireland. Sao Paulo: Humanitas FFLCH/USP.

Nilsen, Don Lee Fred. 1996. Humor in Irish Literature. A Reference Guide. Westport: Greenwood Press.

O’Connell, Walter E. 1996. "Freudian Humor: The Eupsychia of Everyday Life”. In Chapman and Foot, pp. 313-29.

O’Neill, Jamie. 2002. At Swim, Two Boys. London: Scribner.

Palmer, D.J. ed. 1984. Comedy: Developments in Criticism. London: Macmillan.

Sutton, Dana F. 1994. The Catharsis of Comedy. London: Rowman \& Littlefield Publishers Inc.

Sypher, Wylie (ed.). 1980. Comedy. Baltimore \& London: The Johns Hopkins University Press.

Tierney, Mark. 1992. Ireland since 1870. Dublin: C.J. Fallon.

Valente, Joseph. 2005. "Race/Sex/Shame: The Queer Nationalism of At Swim Two Boys". Éire-Ireland, Fall/Winter 40:3 \& 4, 58-84. 